\title{
Norwegian scabies in a 82-year-old female patient
}

\author{
Świerzb norweski u 82-letniej pacjentki
}

Beata Wańczyk-Dręczewska, Agnieszka B. Owczarczyk-Saczonek, Waldemar J. Placek

Department of Dermatology, Sexually Transmitted Diseases and Clinical Immunology, The University of Warmia and Mazury, Olsztyn, Poland

Klinika Dermatologii, Chorób Przenoszonych Drogą Płciową i Immunologii Klinicznej, Uniwersytet Warmińsko-Mazurski w Olsztynie, Polska

Dermatol Rev/Przegl Dermatol 2020, 107, 447-453

DOI: https://doi.org/l0.51/4/dr.2020.101672

\section{CORRESPONDING AUTHOR/ ADRES DO KORESPONDENCJI: \\ Beata Wańczyk-Dręczewska \\ Klinika Dermatologii, \\ Chorób Przenoszonych \\ Drogą Płciowa \\ i Immunologii Klinicznej \\ Uniwersytet Warmińsko-Mazurski \\ Al. Wojska Polskiego 30 \\ 10-292 Olsztyn \\ e-mail: beata.wanczyk@gumed. edu.pl}

\begin{abstract}
Introduction. Scabies is a dermatosis caused by Sarcoptes scabiei, a parasitic mite. The characteristic presentation does not pose diagnostic or therapeutic difficulties. However, the infestation also may have an atypical clinical presentation. Norwegian scabies is a rare, most severe and highly contagious form of the disease.

Objective. This article presents the case of a 82-year-old woman with massive infection with Norwegian scabies. Because of numerous comorbidities and poor general condition the patient required interdisciplinary treatment, both dermatological and internal.

Case report. Due to numerous burdens and poor general condition, the patient required interdisciplinary treatment, both dermatological and internal medicine. During the hospitalization, the patient's condition improved and her skin lesions dissapeared.

Conclusions. Norwegian scabies is a curable disease, but it is of key importance to recognize and treat it early, which prevents the disease from spreading. The diagnostics may difficult because of the non-specific clinical presentation.
\end{abstract}

\section{STRESZCZENIE}

Wprowadzenie. Świerzb jest dermatozą wywoływaną przez gatunek zewnątrzpasożytniczego roztocza Sarcoptes scabiei. Charakterystyczny obraz nie stwarza trudności diagnostycznych i terapeutycznych, jednak infestacja może także przebiegać atypowo. Świerzb norweski jest rzadką, lecz najcięższą i wysoce zakaźną odmianą choroby.

Cel pracy. W artykule przedstawiono przypadek 82-letniej kobiety z masywnym zakażeniem świerzbem norweskim, która z powodu licznych obciążeń i złego stanu ogólnego wymagała interdyscyplinarnego leczenia - dermatologicznego i internistycznego.

Opis przypadku. Z powodu licznych obciążeń i złego stanu ogólnego pacjentka wymagała interdyscyplinarnego leczenia - dermatologicznego i internistycznego. W trakcie hospitalizacji osiągnięto wyrównanie stanu pacjentki oraz ustąpienie zmian skórnych.

Wnioski. Świerzb norweski jest chorobą całkowicie uleczalną, jednak kluczowa jest umiejętność jej rozpoznania i odpowiedniego leczenia, co zapobiega dalszemu rozprzestrzenianiu. Diagnostyka jest utrudniona z powodu niecharakterystycznego obrazu klinicznego.

Key words: Norwegian scabies, scabies, hyperkeratosis.

Słowa kluczowe: świerzb norweski, świerzb, hiperkeratoza. 


\section{INTRODUCTION}

Scabies is a dermatosis caused by Sarcoptes scabiei, a species of extra-parasitic mite. It is estimated that around 300 million people worldwide suffer from scabies [1]. The most common infection occurs through direct contact with the skin of an infected person or through objects that are in long-term contact with it (e.g. clothes, bedding or furniture).

Characteristic presentation of the disease does not pose diagnostic and therapeutic difficulties. However, the infestation may also be atypical. Norwegian scabies is a rare, but the most severe and highly contagious form of the disease, first described in 1848 in patients with leprosy. Predisposing factors include: congenital and acquired immunodeficiency, chronic diseases, mental or physical retardation, cancer, longterm immunosuppressive treatment, old age and malnutrition. Its clinical presentation is characterized by presence of cream, gray or green-yellow colored hyperkeratotic scales. Stacked scales are difficult to separate from the base. In addition, the skin of nail folds is affected, with a thickening and grooving of nail plates. Lesions are typically located on the face, elbows, knees, torso, feet, hands, and the scalp. The sensation of itching, which is characteristic of the classic form of the disease, is reduced or absent in case of Norwegian scabies [2]. The patient's skin contains a huge number of parasites, about 1-2 million [3], while in the classic form, this number reaches 20 [2]. Laboratory tests of peripheral blood show high levels of IgE and eosinophilia [3].

\section{CASE REPORT}

The 82-year-old woman was transferred to the Department of Dermatology, Sexually Transmitted Diseases and Clinical Immunology from the Internal Medicine Ward due to severe skin lesions. According to the patient, lesions appeared 2.5 years before the admission. For this reason, the patient had remained under supervision of a local Dermatology Clinic. She applied topical treatment in the form of prescription ointments. The patient's son and daughter-in-law who lived with the patient did not show any dermatological pathologies.

The patient was hospitalized in the Internal Medicine Ward due to poor general condition, heart failure, arterial hypertension, diabetes mellitus treated with oral medications, hyperuricemia, iron deficiency anemia and exudative pneumonia.

On admission to the Department, physical examination revealed generalized erythematous-papular lesions with numerous excoriations. In addition, strong confluent lesions in the form of hyperkeratotic layers of yellow-gray masses were observed,

\section{WPROWADZENIE}

Świerzb jest dermatozą wywoływaną przez gatunek zewnątrzpasożytniczego roztocza Sarcoptes scabiei. Szacuje się, że na świecie na świerzb choruje ok. $300 \mathrm{mln}$ ludzi [1]. Do zakażenia dochodzi najczęściej poprzez bezpośredni kontakt ze skórą zarażonej osoby lub za pośrednictwem przedmiotów pozostających z nią w długotrwałym kontakcie (np. ubrania, pościel czy meble).

Charakterystyczny obraz nie stwarza trudności diagnostycznych i terapeutycznych, jednak infestacja może także przebiegać atypowo. Świerzb norweski jest rzadką, lecz najcięższą i wysoce zakaźną odmianą tej choroby, po raz pierwszy opisaną w $1848 \mathrm{r}$. u chorych na trąd. Do czynników predysponujących zalicza się: wrodzone i nabyte niedobory odporności, choroby przewlekłe, niedorozwój umysłowy lub fizyczny, choroby nowotworowe, długotrwałe leczenie immunosupresyjne, podeszły wiek oraz niedożywienie. Charakterystyczne w obrazie klinicznym jest występowanie hiperkeratotycznych łusek o barwie kremowej, szarej lub zielonożółtej. Nawarstwione łuski trudno jest oddzielić od podłoża. Ponadto zajęta jest skóra wałów paznokciowych, a płytki są pogrubiałe i pobruzdowane. Zmiany typowo umiejscowione są na twarzy, łokciach, kolanach, tułowiu, stopach, rękach i skórze owłosionej głowy. Uczucie świądu, które jest charakterystyczne dla klasycznego obrazu choroby, w przypadku świerzbu norweskiego jest osłabione lub w ogóle nie występuje [2]. Na skórze chorego znajduje się ogromna liczba pasożytów, ok. 1-2 mln [3], podczas gdy w klasycznej postaci dochodzi ona do 20 [2]. W badaniach laboratoryjnych we krwi obwodowej stwierdza się wysokie stężenie IgE oraz eozynofilię [3].

\section{OPIS PRZYPADKU}

Kobieta 82-letnia została przekazana do Kliniki Dermatologii, Chorób Przenoszonych Drogą Płciową i Immunologii Klinicznej z Oddziału Chorób Wewnętrznych z powodu nasilonych zmian skórnych. Według pacjentki wykwity pojawily się 2,5 roku przed przyjęciem. $Z$ tego powodu pozostawała pod opieką poradni dermatologicznej w miejscu zamieszkania, stosowała leczenie miejscowe w postaci maści recepturowych. Mieszkający z chorą syn i synowa nie mieli zmian skórnych.

Pacjentka była hospitalizowana na oddziale chorób wewnętrznych z powodu złego stanu ogólnego, niewydolności serca, nadciśnienia tętniczego, cukrzycy typu 2 leczonej lekami doustnymi, hiperurykemii, niedokrwistości z niedoboru żelaza oraz wysiękowego zapalenia płuc.

W badaniu fizykalnym przy przyjęciu do Kliniki stwierdzono uogólnione zmiany o charakterze rumieniowo-grudkowym z licznymi przeczosami. Ponadto 
especially on the limbs and face, showing deep, linear cracks with purulent discharge (figs. 1, 2). The patient reported slight itching and pain around skin lesions.

During the hospitalization, a biopsy was taken for histopathological examination, skin scrapings for microscopic examination - scabies mites were detected (figs. 3, 4). Swabs from the throat, nasal cavity and skin clefts were collected for bacteriological tests - the following were cultured: in the throat - Candida albicans and Staphylococcus aureus; in the nasal cavity - Pseudomonas aeruginosa and Proteus mirabilis; in skin clefts - Pseudomonas aeruginosa.

The following abnormal results of laboratory tests were found: IgE $2500 \mathrm{IU} / \mathrm{ml}$, white blood cells $(\mathrm{WBC}): 14.27 \times 10^{3} / 1$, creatinine: 1.74 , estimated glomerular filtration rate (eGFR): $28.2 \mathrm{ml} /$ min, C-reactive protein (CRP): $71.8 \mathrm{mg} / 1$. Piperacillin was administered according to the antibiotic susceptibility test (continuation of the treatment recommended in the previous Ward), along with a $\beta$-blocker, a sulfonylurea derivative (discontinued on the second day of hospitalization due to hypoglycemia), sedatives, and intravenous fluids. Sulfur-salicylic ointment and Wilkinson's ointment were applied topically for two days, which resulted in improvement of skin lesions.

During hospitalization, the patient was calm in the morning, agitated at night, with no logical contact. A significant deterioration in general condition was observed, with episodes of hypoglycemia and anuria. Control laboratory tests showed a decrease in CRP - $55.9 \mathrm{mg} / 1$, but also an increase

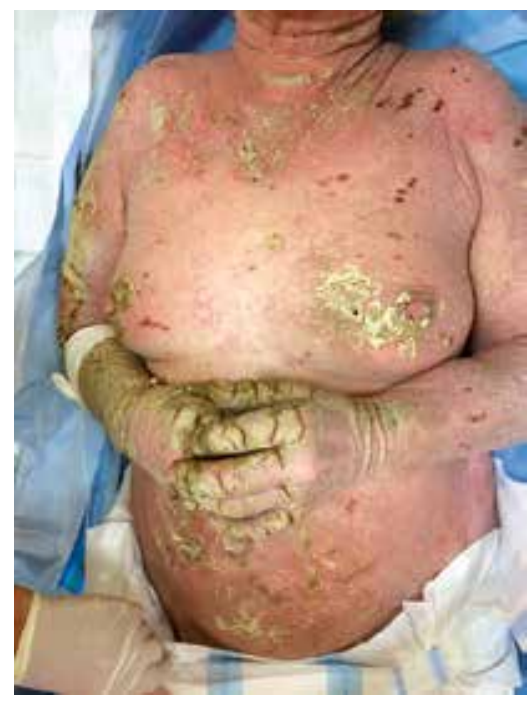

Figure I. Massive lesions in localizations characteristic of Norwegian scabies; linear deep cracks within the built-up scale

Rycina I. Masywne zmiany o charakterystycznym dla świerzbu norweskiego umiejscowieniu; linijne, głębokie pęknięcia w obrębie nawarstwionej łuski obecne były nasilone zlewne zmiany w postaci hiperkeratotycznych nawarstwień żółtoszarych mas, szczególnie na kończynach i twarzy, w obrębie których widoczne były linijne głębokie pęknięcia z ropną wydzieliną (ryc. 1,2). Pacjentka zgłaszała niewielki świąd i dolegliwości bólowe w okolicach zmian skórnych.

W trakcie hospitalizacji pobrano wycinek do badania histopatologicznego i zeskrobiny ze skóry do badania mikroskopowego, w których wykryto świerzbowce (ryc. 3,4$)$. Pobrano wymazy z gardła, jamy nosowej oraz rozpadlin skórnych do badań bakteriologicznych. Wyhodowano: w gardle - Candida albicans oraz Staphylococcus aureus; $\mathrm{w}$ jamie nosowej - Pseudomonas aeruginosa i Proteus mirabilis; w rozpadlinie skórnej - Pseudomonas aeruginosa.

W badaniach laboratoryjnych stwierdzono następujące odchylenia od normy: IgE $2500 \mathrm{IU} / \mathrm{ml}$, białe krwinki (WBC): 14,27 × 103/1, kreatynina: 1,74, szacunkowy współczynnik przesączania kłębuszkowego (eGFR): 28,2 ml/min, białko C-reaktywne (CRP): 71,8 mg/1. Zgodnie $\mathrm{z}$ antybiogramem zastosowano antybiotyk - piperacylinę (kontynuacja zaleconego na poprzednim oddziale), $\beta$-bloker, pochodną sulfonylomocznika (wstrzymano w drugiej dobie hospitalizacji z uwagi na hipoglikemię), leki uspokajające, płyny dożylne. Miejscowo stosowano maść siarkowo-salicylową i maść Wilkinsona przez dwie doby, uzyskując poprawę w zakresie zmian skórnych.

W czasie hospitalizacji pacjentka była spokojna w godzinach porannych, w nocy pobudzona, bez kontaktu logicznego. Obserwowano znaczne pogorszenie stanu ogólnego z epizodami hipoglikemii i anurią. W kontrolnych badaniach laboratoryjnych wykazano zmniejszenie CRP - 55,9 mg/l, a także wzrost leukocytozy $\left(15,35 \times 10^{3} / 1\right)$ i stężenia kreatyniny $(2,66 \mathrm{mg} / \mathrm{dl})$ oraz NTpro-BNP (12917 pg/ml). Ze względu na cechy zaostrzonej niewydolności serca oraz pogorszenie parametrów nerkowych pacjentkę przekazano do oddziału chorób wewnętrznych w celu dalszego leczenia.

W momencie przyjęcia do oddziału chorób wewnętrznych kobieta była w stanie ciężkim, występo-

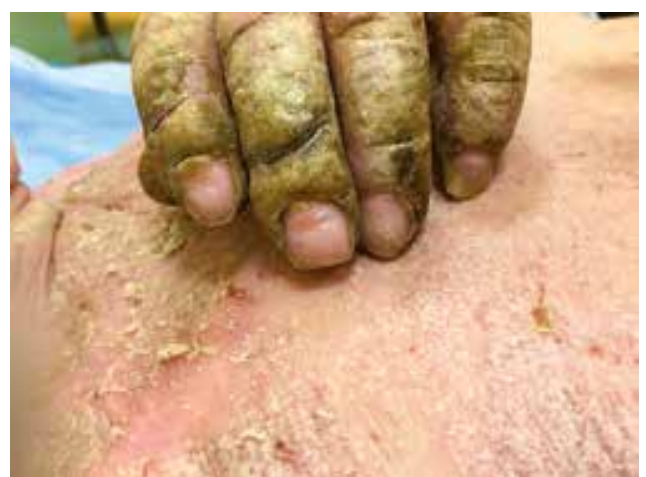

Figure 2. Involvement of nails with grooving

Rycina 2. Zajęcie paznokci z pobruzdowaniem 


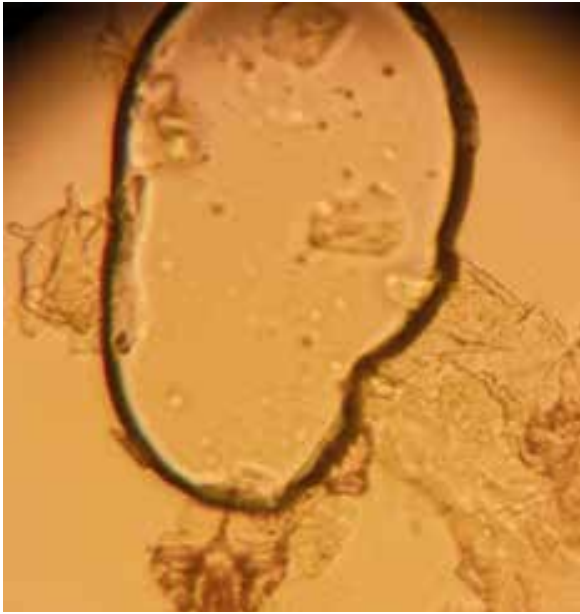

Figure 3. Scabies in the microscopic specimen Rycina 3. Świerzbowce w materiale mikroskopowym

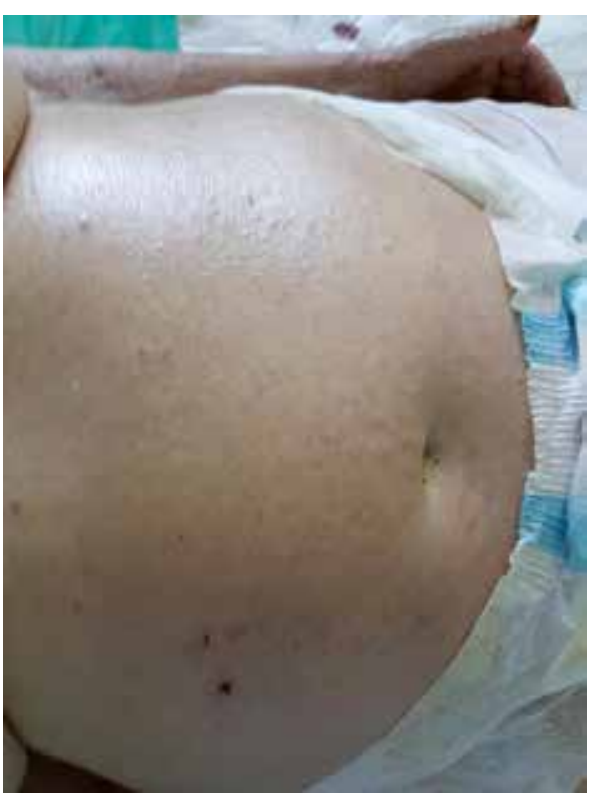

Figure 5. The appearance of changes at the time of discharge from the Internal Medicine Ward. Compared to the state on admission. A significant improvement in skin lesions is noticeable

Rycina 5. Wygląd zmian w momencie wypisu z oddziału chorób wewnętrznych. W porównaniu ze stanem przy przyjęciu zauważalna znaczna poprawa w zakresie zmian skórnych

in leukocytosis $\left(15.35 \times 10^{3} / 1\right)$ and creatinine level $(2.66 \mathrm{mg} / \mathrm{dl})$ and NT pro-BNP $(12917 \mathrm{pg} / \mathrm{ml})$. Due to symptoms of exacerbation of the heart failure and deterioration of renal parameters, the patient was transferred to the Internal Medicine Ward for further treatment.

At the time of admission to the Internal Medicine Ward, the woman was in severe condition with disturbances of consciousness and features of cardio-respiratory failure. Laboratory tests revealed leukocytosis, low blood glucose levels and elevated inflammatory parameters and creatinine

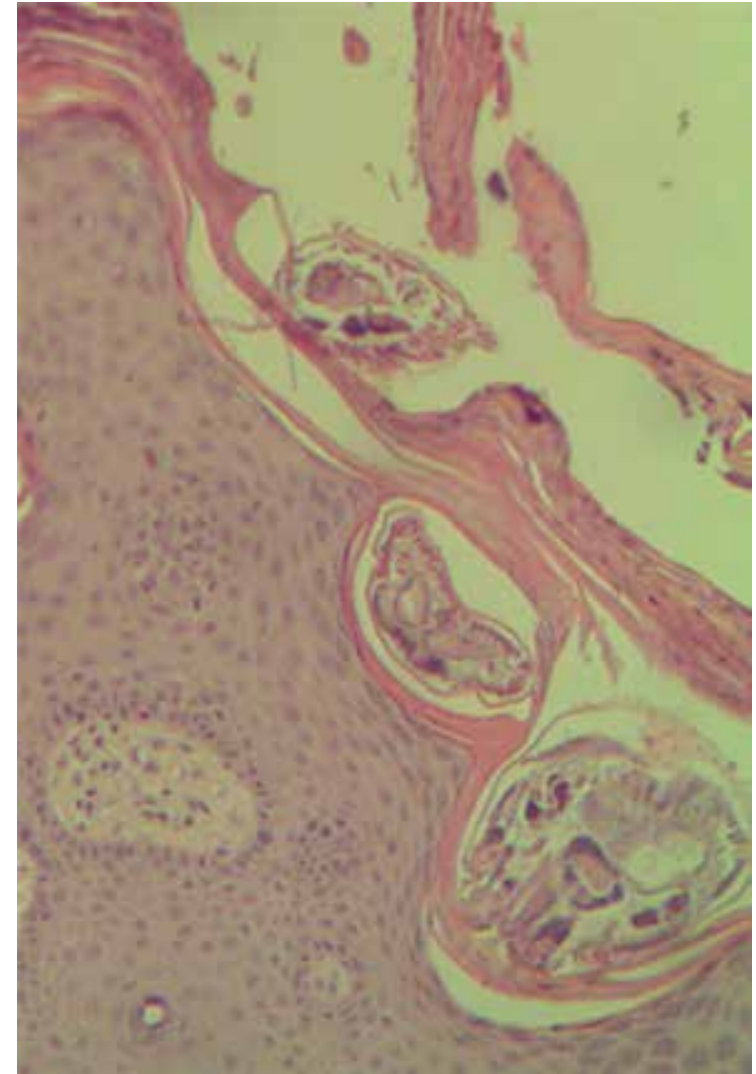

Figure 4. Scabies in the histopathological material

Rycina 4. Świerzbowce w materiale histopatologicznym

wały u niej zaburzenia świadomości oraz cechy niewydolności krążeniowo-oddechowej. W badaniach laboratoryjnych stwierdzono leukocytozę, niskie wartości glikemii oraz podwyższone parametry stanu zapalnego i stężenia kreatyniny (WBC: 18,5 × 103/1, GLU: $35 \mathrm{mg} / \mathrm{dl}$, CRP: $57 \mathrm{mg} / \mathrm{l}$, kreatynina: 2,51 mg/dl). Zastosowano intensywną płynoterapię - PWE oraz glukozę, antybiotykoterapię oraz zalecone w Klinice Dermatologii leczenie miejscowe, dołączając maść z kwasu bornego. Po kilku dniach osiągnięto istotną poprawę stanu ogólnego pacjentki (WBC: 11,2 × 103/1, GLU: $91,1 \mathrm{mg} / \mathrm{dl}$, kreatynina: $0,82 \mathrm{mg} / \mathrm{dl}$ ) oraz ustąpienie zmian skórnych (ryc. 5).

\section{OMÓWIENIE}

Ze względu na niecharakterystyczny obraz kliniczny rozpoznanie świerzbu norweskiego jest trudne. Schemat diagnostyczny przedstawiono $\mathrm{w}$ tabeli 1 $[2,4,5]$. Kluczowe jest wykrycie świerzbowców w badaniu dermatoskopowym, mikroskopowym lub histopatologicznym. Do rozprzestrzeniania choroby może prowadzić brak rozpoznania oraz niewłaściwe lub nieskuteczne leczenie. W diagnostyce różnicowej należy wziąć pod uwagę łuszczycę, przewle- 
levels (WBC: 18.5 10³/, GLU: $35 \mathrm{mg} / \mathrm{dl}$, CRP: $57 \mathrm{mg} / 1$, creatinine: $2.51 \mathrm{mg} / \mathrm{dl})$. Intensive fluid therapy - compound electrolyte fluid and glucose, antibiotic therapy and the topical treatment recommended in the Department of Dermatology were used, with introduction of the boric acid ointment. After a few days, the patient's general condition improved significantly (WBC: 11.2 10³/1, GLU: 91.1 $\mathrm{mg} / \mathrm{dl}$, creatinine: $0.82 \mathrm{mg} / \mathrm{dl}$ ) and skin lesions disappeared (fig. 5).

\section{DISCUSSION}

Due to the non-specific clinical presentation, the diagnosis of Norwegian scabies is difficult. The diagnostic scheme is presented in table $1[2,4,5]$. Detection of mites by dermoscopy, microscopy or histopathology is crucial. Misdiagnosis of the disease, as well as its improper or ineffective treatment may lead to its dissemination. The differential diagnosis should include psoriasis, chronic allergic eczema, seborrheic dermatitis, lichen planus and Darier's disease [2].

In the described case, deterioration of the patient's general condition was most likely caused by both exacerbation of heart failure and the treatment applied. There are reports of poisoning with externally applied salicylic acid in the literature. Symptoms include nausea, vomiting, confusion, dizziness, tinnitus, delirium, dementia and coma. Metabolic kły wyprysk alergiczny, łojotokowe zapalenie skóry, liszaj płaski oraz chorobę Dariera [2].

$\mathrm{W}$ przedstawionym przypadku pogorszenie stanu ogólnego pacjentki było najprawdopodobniej spowodowane zarówno zaostrzeniem niewydolności serca, jak i zastosowanym leczeniem. W piśmiennictwie opisywane są przypadki zatrucia kwasem salicylowym stosowanym zewnętrznie. Objawy obejmują: nudności, wymioty, splątanie, zawroty głowy, szumy uszne, majaczenie, otępienie oraz śpiączkę. Dochodzi do zaburzeń metabolicznych - kwasicy metabolicznej, zasadowicy oddechowej oraz hiper- lub hipoglikemii [6]. Wchłanianie kwasu salicylowego wynosi do $60 \%$ przy nieuszkodzonej skórze [6] i zwiększa się znacząco przy dermatozach, szczególnie u dzieci i osób w podeszłym wieku. Zastosowanie u pacjentki preparatu $10 \%$ kwasu salicylowego było konieczne ze względu na jego działanie keratolityczne, ponieważ pogrubiała łuska uniemożliwiała przenikanie leków miejscowych.

Zakażeniu świerzbowcem często towarzyszy wtórne nadkażenie paciorkowcami i gronkowcami, głównie S. pyogenes i S. aureus [7]. Dochodzi do niego przede wszystkim poprzez intensywne drapanie, ale również same roztocza mogą uczestniczyć w transmisji - paciorkowce i gronkowce wyizolowano z odchodów świerzbowców [7]. Patogeny te prowadzą do powstawania czyraków, zapalenia tkanki łącznej lub naczyń chłonnych. S. pyogenes jest także czynnikiem

Table I. Diagnostics of Norwegian scabies

Tabela I. Diagnostyka świerzbu norweskiego

Clinical presentation/Obraz kliniczny Skin lesions in form of hyperkeratotic, yellowish-gray scale/Zmiany skórne w postaci hiperkeratotycznych, nawarstwionych, żóltoszarych łusek

Atypical location: scalp, face, elbows, knees, hands, feet/Nietypowa lokalizacja: owłosiona skóra głowy, twarz, łokcie, kolana, ręce, stopy

Massive subungual hyperkeratosis/Masywna hiperkeratoza podpaznokciowa Itching is less intense than in the classic form or is absent/Świąd mniej nasilony niż w postaci klasycznej lub w ogóle nie występuje

\begin{tabular}{ll}
\hline $\begin{array}{l}\text { Microscopic examination/Badanie } \\
\text { mikroskopowe }\end{array}$ & $\begin{array}{l}\text { Addition of } \mathrm{KOH} \text { to the specimen allows observation of the parasite or its eggs/ } \\
\text { Po dodaniu do preparatu KOH możliwe jest uwidocznienie pasożyta lub jego jaj }\end{array}$ \\
\hline Dermoscopic examination/Badanie & Brown or black triangle structures (oral cavity with anterior legs) - delta wing jet sign/ \\
dermatoskopowe & $\begin{array}{l}\text { Brunatne lub czarne, trójkątne struktury (otwór gębowy z przednimi odnóżami) - } \\
\text { delta wing jet sign }\end{array}$ \\
& S or Z-shaped scabies dens topped with a black, round structure (scabies)/ \\
& Nory świerzbowcowe w kształcie litery S lub Z zakończone czarną, okrągłą strukturą \\
& (świerzbowiec) \\
\hline Histopathological examination/Badanie & Epidermis: acanthosis, parakeratosis and intercellular edema, eosinophilic \\
histopatologiczne & infiltration; scabies form fissures in the upper part of their dens/Naskórek: akantoza, \\
& parakeratoza i obrzęk międzykomórkowy, naciek eozynofilowy; w górnej części nory \\
& świerzbowcowe tworzą szczeliny \\
& Dermis: superficial, perivascular infiltration of lymphocytes and histiocytes, rarely \\
& eosinophils/Skóra właściwa: powierzchowny, okołonaczyniowy naciek z limfocytów \\
& i histiocytów, rzadko eozynofilów \\
\hline Additional diagnostic tests/Dodatkowe & lodine test - staining of scabies dens/Test z jodyną - wybarwienie nor \\
testy diagnostyczne & świerzbowcowych \\
& Tetracycline test - fluorescence of dens under a Wood's lamp/Test z tetracykliną - \\
& fluorescencja nor w lampie Wooda
\end{tabular}


disorders develop - metabolic acidosis, respiratory alkalosis, and hyper - or hypoglycemia [6]. Absorption of salicylic acid is up to $60 \%$ in intact skin [6], increasing significantly with dermatoses, especially in children and elderly. The use of the $10 \%$ salicylic acid preparation was necessary for the patient due to its keratolytic effect, as the thickened scale prevented penetration of topical preparations.

Infection with scabies is often accompanied by secondary superinfection with streptococci and staphylococci, mainly S. pyogenes and S. aureus [7]. It occurs mainly as a consequence of intense scratching, but mites themselves can also participate in transmission - streptococci and staphylococci were isolated from scabies excrement [7]. These pathogens lead to formation of boils, cellulitis or lymphangitis. S. pyogenes is also a causative agent of glomerulonephritis, rheumatic fever and even sepsis [7].

The patient was only treated with topical treatment with satisfactory effect. The therapeutic option recommended by the European IUSTI guidelines is oral ivermectin combined with topical preparations [8]. It is used in particularly severe cases of scabies, in Norwegian scabies, in immuno-noncompetent patients and in those who cannot be treated with topical agents. The recommended dose is $200 \mu \mathrm{g} / \mathrm{kg}$ b.w., administered three times on days 1,2 . and 8 , and if lesions persist, additionally on days 9 and 15, and days 22 and 29. The oral preparation of ivermectin is not registered in Poland, it is available only as the bearer prescription medicinal product.

\section{CONCLUSIONS}

Norwegian scabies is a rare but the most severe and highly contagious form of scabies. Correct diagnosis and treatment of this disease is crucial as it prevents it from spreading and allows avoiding complications. The example of the case presented above shows that the diagnosis of Norwegian scabies is difficult due to the non-specific clinical presentation and a minor sensation of itching. Due to the fact that oral ivermectin is not available for the treatment of scabies in Poland, patient care should include intensive topical treatment.

\section{CONFLICT OF INTEREST}

The authors declare no conflict of interest. wywołującym kłębuszkowe zapalenie nerek, gorączkę reumatyczną, a nawet posocznicę [7].

U pacjentki zastosowano wyłącznie leczenie miejscowe z dobrym efektem. Opcją terapeutyczną zalecaną przez europejskie wytyczne IUSTI jest doustne podanie iwermektyny w połączeniu ze stosowaniem preparatów miejscowych [8]. Lek ten jest wykorzystywany w szczególnie nasilonych przypadkach świerzbu, w świerzbie norweskim, u pacjentów immunoniekompetentnych oraz takich, u których nie można zastosować leczenia miejscowego. Rekomendowana dawka to $200 \mu \mathrm{g} / \mathrm{kg}$ m.c., podana trzykrotnie $\mathrm{w}$ dniach 1., 2. i 8., a w razie dalszego utrzymywania się zmian dodatkowo w dniach 9. i 15. oraz 22. i 29. Doustny preparat iwermektyny nie został zarejestrowany w Polsce, dostępny jest jedynie w ramach importu docelowego.

\section{WNIOSKI}

Świerzb norweski jest rzadką, lecz najcięższą i wysoce zakaźną postacią świerzbu. Umiejętność diagnostyki i leczenia tej choroby jest kluczowa, ponieważ pozwala na zatrzymanie jej rozprzestrzeniania się, a także uniknięcie związanych z nią powikłań. Powyższy przypadek pokazuje, że rozpoznanie świerzbu norweskiego jest trudne $z$ powodu niecharakterystycznego obrazu klinicznego i niewielkiego świądu. Z uwagi na niedostępność w Polsce doustnego preparatu iwermektyny do leczenia świerzbu opieka nad pacjentem powinna obejmować intensywną terapię miejscową.

\section{KONFLIKT INTERESÓW}

Autorzy nie zgłaszają konfliktu interesów. 


\section{References}

\section{Piśmiennictwo}

1. Hengge U.R., Currie B.J., Jäger G., Lupi O., Schwartz R.A.: Scabies: ubiquitous neglected skin disease. Lancet Infect Dis 2006, 6, 769-779.

2. Traczewski P., Bielawska I., Różewicka-Czabańska M., Marchlewicz M., Maleszka M.: Świerzb - najnowsze zasady diagnostyki, leczenia i profilaktyki. Dermatologia po Dyplomie 2016, 3, 42-50.

3. Walton S.F., Currie B.J.: Problems in diagnosing scabies, a global disease in human and animal populations. Clin Microbiol Rev 2007, 20, 268-279.

4. Hamodat M.: Scabies (mite). PathologyOutlines.com website. http://www.pathologyoutlines.com/topic/skinnontumorscabies.html. Accessed August 18 ${ }^{\text {th }}, 2020$.

5. Srinivas S., Herakal K.C., Murthy S.K., Suryanarayan S.: Dermoscopic study of scabies in children. Indian J Paediatr Dermatol 2019, 20, 46-51.

6. Madan R., Levitt J.: A review of toxicity from topical salicylic acid preparations. J Am Acad Dermatol 2014, 70, 788-792.

7. McCarthy J.S., Kemp D.J., Walton S.F., Currie B.J.: Scabies: more than just an irritation. Postgrad Med J 2004, 80, 382-387.

8. Salavastru C.M., Chosidow O., Boffa M.J., Janier M., Tiplica G.S.: European guideline for the management of scabies. J Eur Acad Dermatol Venereol 2017, 31, 1248-1253.

Received: 25.11 .2019

Accepted: 7.09 .2020

Otrzymano: 25.11.2019 r

Zaakceptowano: $7.09 .2020 \mathrm{r}$.

How cite this article

Wańczyk-Dręczewska B., Owczarczyk-Saczonek A.B., Placek W.J.: Norwegian scabies in a 82-year-old female patient. Dermatol Rev/Przegl Dermatol 2020, 107, 447-453. DOI: https://doi.org/10.5114/dr.2020.101672. 